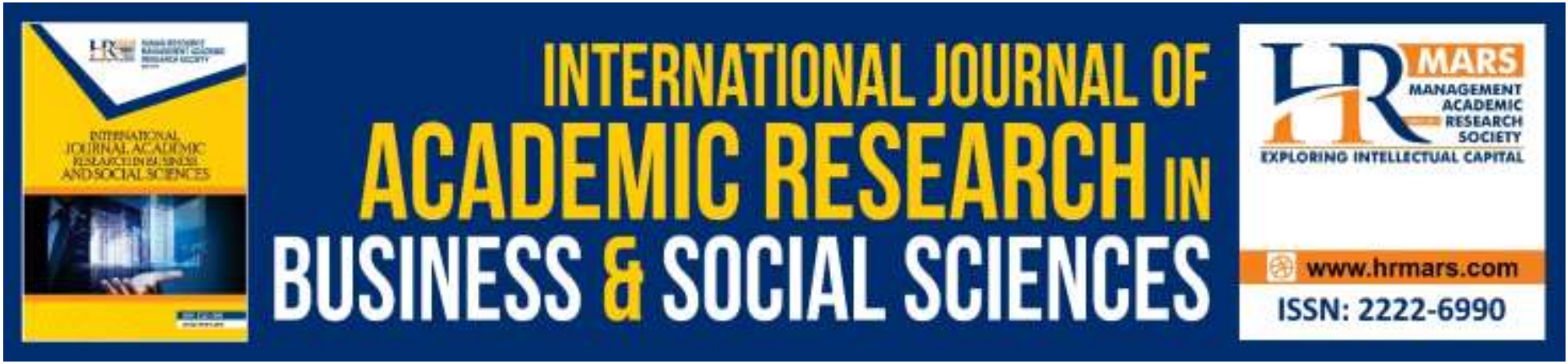

\title{
Impact of Board Diversity on Corporate Social Responsibility (CSR) on Malaysian Public Listed Companies
}

Suzila Mohamed Yusof, Najihatul Amirah Nordin, Mohamad Jais, Salawati Sahari

To Link this Article: http://dx.doi.org/10.6007/IJARBSS/v9-i7/6209

DOI: $10.6007 /$ IJARBSS/v9-i7/6209

Received: 09 May 2019, Revised: 12 June 2019, Accepted: 26 June 2019

Published Online: 09 July 2019

In-Text Citation: (Yusof, Nordin, Jais, \& Sahari, 2019)

To Cite this Article: Yusof, S. M., Nordin, N. A., Jais, M., \& Sahari, S. (2019). Impact of Board Diversity on Corporate Social Responsibility (CSR) on Malaysian Public Listed Companies. International Journal of Academic Research in Business and Social Sciences, 9(7), 1049-1069.

Copyright: (C) 2019 The Author(s)

Published by Human Resource Management Academic Research Society (www.hrmars.com)

This article is published under the Creative Commons Attribution (CC BY 4.0) license. Anyone may reproduce, distribute, translate and create derivative works of this article (for both commercial and non-commercial purposes), subject to full attribution to the original publication and authors. The full terms of this license may be seen

at: http://creativecommons.org/licences/by/4.0/legalcode

\section{Vol. 9, No. 7, 2019, Pg. 1049 - 1069}

Full Terms \& Conditions of access and use can be found at http://hrmars.com/index.php/pages/detail/publication-ethics 


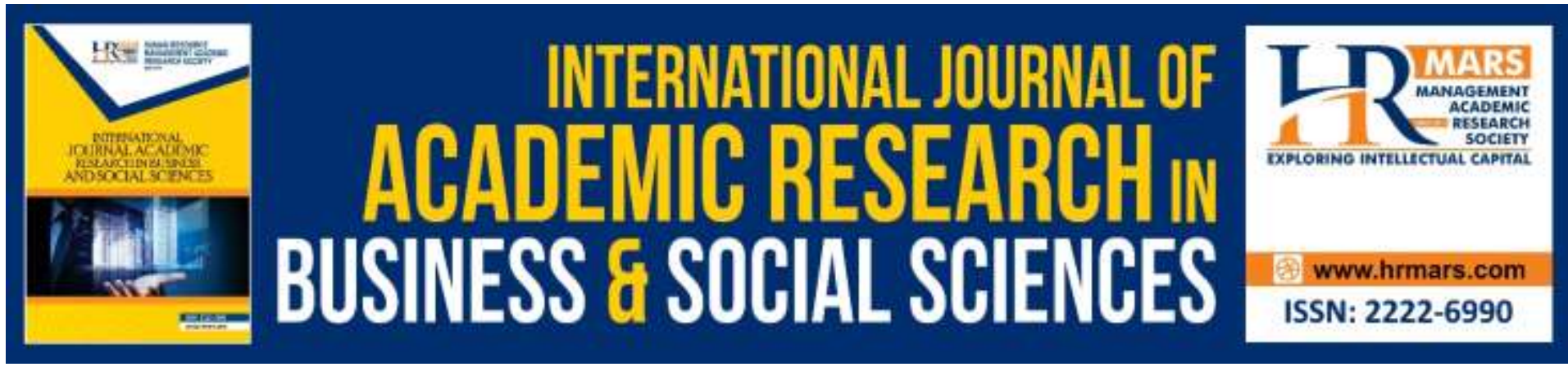

\title{
Impact of Board Diversity on Corporate Social Responsibility (CSR) on Malaysian Public Listed Companies
}

\author{
Suzila Mohamed Yusof ${ }^{1}$, Najihatul Amirah Nordin, Mohamad \\ Jais, Salawati Sahari \\ Faculty of Economics and Business, Universiti Malaysia Sarawak, Malaysia \\ Corresponding Author's Email: ${ }^{1}$ mysuzila@unimas.my
}

\begin{abstract}
Different theories and empirical research have been done and suggested to define and clarify how board diversity give impacts to corporate social responsibility (CSR). This study examines the impact of board diversity towards CSR based on the 50 Malaysian Public Listed Companies within the year 2010 to 2016. Board diversity examines the board gender, board age, board size, board independence and board tenure toward CSR. The methodology of the study used Ordinary Least Square (OLS) regression to determine the relationship of CSR and all variables under the board diversity. Various analysis being done starting from the Pearson Correlation Coefficient Test and Descriptive Statistics Analysis. Model determination in this study also being analysed by using The Breusch \& Pagan Lagrange Multiplier (LM Test) and Hausman Test. Based on the findings, the regression results show the diversification of the board, and other control variables had a positive relationship with CSR. The results revealed that the impact of board diversity gives positive relationship towards the CSR performance among the companies except for board tenure that brings negative relationship towards CSR performance.
\end{abstract}

Keywords: Board Diversity, Corporate Social Responsibility, Global Reporting Initiative, Corporate Governance

\section{Introduction}

The Malaysian corporate participants are getting more concerned about putting CSR activities in order for survival growth. CSR means regarding the behaviour of businesses over and above what is ordinarily required by regulatory bodies and legal requirements, not least because it is voluntarily practised but because businesses deem it to be in their long-term interest to do so (Shirley et al., 2009). CSR field covers all the knowledge area about the stakeholder's relations, goods and services, contribution in the public development projects, and environmental reporting. Additionally, as a modern management concept, CSR attracts public interest entities. 
CSR can be defined as the current requirement by a certain organization for the improvement of commercial development. Furthermore, it uses for clarifying the quality of life for all internal and external users of the companies in concerns of community and development of society. In Malaysia, CSR shows accountability towards maximizing profits of the shareholders and to observe the needs of all the related stakeholders such as employees, customers, suppliers and others.

Successful CSR management should lead to voluntary CSR reporting as a complement to classical financial accounting (e.g., financial statements, group/management reports) (Velte, 2017). CSR disclosures may be included in the annual report or be separated into a "standalone" CSR report (Rao and Tilt, 2016). From the CSR reports, it covers four dimensions of CSR which are the social performance, environmental performance, economic performance and corporate governance issues in line with generally recognized CSR reporting standards such as from the guidelines of the Global Reporting Initiative (GRI).

Nevertheless, from every successful management of CSR, there is a board diversity that plays a critical role in monitoring the company's performance. The board diversity is able to give positive CSR level of initiatives involving companies' engagement (Rao, 2016). Selection of board members can be done in pursue of CSR objectives that have selected criteria's such as good qualification, knowledge and varied value (Rao, 2016). Besides, by having a different characteristic among the board of directors, it may show to community on how the companies assign with social fairness (Bilimoria, 2000, Miller and Triana 2009); their standard faithfulness and favorable working environment (Miller and Triana 2009); the performance of organizations (Galbreath, 2011) and be responsible and concern towards women and minorities needs (Bear et al. 2010).

Board diversity can be defined as the variety background within the board representative where it has a boundless value in diversity of age, knowledge, expertise and gender requirement within board directors (Knippenberg et al. 2004). It can be categorized into visible or less visible. Under a visible diversity can be gender, nationality, ethnicity and age while for less visible diversity is knowledge, education, experience, role, profession and organizational membership (Kang et al. 2007). Accordingly, this study analyses five factors of board diversity which are board gender, board age, board size, board independence and board tenure to examine the CSR's performance of CSR.

Van and Ingley (2003) mentions that board diversity in board representative is regarding the differences among boards' virtue and decisions. Board diversity can accomplish to overcome a good result in their operation. This involves the financial achievement of the companies. Hence, in order to fulfil the needs and interests of diverse stakeholders, the essential role of the commissioner's board should have varieties of perspectives that not solely providing short-term orientations related to financial performance, but also in long-term corporate sustainability (Handajani, Subroto, T., \& Saraswati, 2014).

Board diversity plays an imperative role in an organization in controlling corporate governance. The diversity and composition of the board of commissioners should have valuable skills, knowledge, background and expertise in enhancing the quality of CSR in terms of decision-making strategies and policies at both individual and group levels. Notwithstanding, whenever there is a lack of diversity and homogeneous boards in management, this lead to general failures and weaknesses of governance such as conflict of interest, management of cost, illegal insider trading or misleading financial statements. 
Alternately, the board diversity showed an increased representation of moral and ethical views in the decision-making process, reduce myopic decision making, enhance new ideas better problem-solving, and enhance corporate strategic planning and accountability (Handajani, Subroto, \& Saraswati, 2014). Additionally, the representation of board diversity can raise the ethical corporate culture and leads to a better understanding of the company's market position, creativity and innovation as well as more effective problems.

\section{Problem Statement}

It is important to study the diversification of board towards the CSR because it shows on how does the diversity of board directors influences in the CSR performance. The significance in assessing the CSR performance (Kakabadse, 2007) has been observed all over the world. To be include, the implication of CSR in Malaysia becomes a pressing issue nowadays but there is still have a limited research about CSR. Some surveys have indicated that although Malaysian companies are performing well in international either in the quantity or the quality of CSR performance, but there is still need to improve in terms of managing operations. There has been unprecedented wave of growth of voluntarily board diversity performance disclosure in CSR report over the last decade.

CSR report was born as a tool to support the internal effort of company as well as a feedback to the increasing demand of organization from stakeholders. The diversity of board can improve the capability of companies in trying to provide what the stakeholder wants for a company's sake. There is an issue that the corporate managers are required to satisfy the need of all groups who have a stake in the business which is the stakeholders for maximizing the firm value (Freeman et al., 2004). Whereas, Jensen $(2001,2002)$ had indicates that the firms need to build the relationships with various stakeholder groups in order to maximize the shareholder value. However, firms could suffer if both monetary and the company reputation losses from failing to meet the management's interest with the stakeholders.

What is the main reason for CSR performance fails the expectation from stakeholders? The effective stakeholder management is a critical requirement for firm success. Therefore, boards of directors, as the representatives of shareholders need to be responsible on their role as a shareholder in overseeing the creation and execution of management's plans to balance the interest of multiple stakeholders. In this study, it will examine the effectiveness of diverse boards in overseeing the management's performance on the stakeholders. In other words, this study will examine the effect of diversification in board between CSR where it might show the positive relationship or negative relationship.

Moreover, the diversity of board member in companies will help to produce a better of CSR performance. From this study further outlines, board diversity in a company have few factor that influences the company's contribution towards CSR but there are five factors which had been examined to know either it positively correlated or negatively correlated to CSR in Malaysia. Therefore, further research is needed to provide more information on the diversification of board towards CSR and to confirm the generalization of these findings.

To conclude that this study is regarding the diversification of board and performance of CSR will be investigating more furthers to displays the impact of board gender, board age, board size, board independence and board tenure towards the CSR. It is important to learn on how the diversity in a board level can influenced the board decisions and the interest of stakeholders because the diversity of board can shorten the effectiveness of board in operating its duty and making a united decision. 


\section{Literature Review \\ Theories Involved \\ Stakeholder Theory}

According to ljas (2012), stakeholder theory indicates that the companies must achieve their fiduciary duty to stakeholders and protecting their long term of interest where it might involve in any role of board directors. In other words, the managers are responsible to maximize the shareholder return which needs to make it balance between the interests of shareholders and the other stakeholder group.

The stakeholder is known as an individual or group who can be influenced by the achievement of an organization's purpose (Harjoto, Laksamana, \& Lee, 2014). The stakeholder can be either employees, shareholders, creditors, consumers and any local communities. This theory which had been introduced by Dr.F. Edward Freeman in the year 1984 mainly focuses on the resource-based view and market-based view in sociopolitical level. Stakeholder theory also attempts to state the specific stakeholders of a company and then study on the situations how managers negotiate and handle with these parties which are stakeholders.

Companies which had tried to increase their value by endures the activities of CSR and enhances a stronger relationship between stakeholders. Moreover, the stakeholder theory gives the impact to the risk management were at the same time tackle a various type of risk which balancing the company's portfolio and the interest of stakeholder which it can maximize the shareholder's wealth.

\section{Resource Dependence Theory}

Resource dependence theory provides a perspective that the organization seeks to control external environment by choosing the resources needed to keep survive (Pfeffer, 1972). Particularly, the board of directors are the linkage mechanism that contributes critical sources to the companies which are includes the authority, guidance and consultations (Hillman and Dalziel, 2003). Resource dependence theory is usually being used by scholars to justify the responsibility of boards in reaching the companies' goals towards a better of CSR. However, there is claims argue that a certain board directors are responsible to serve the efficient management in order to provide an excellent resource dependence role. Besides, there is another argument from a previous study which reveals that a set of experiences boards is able to bridge the connection between corporate relationships with external parties and large society (Selsky \& Parker, 2005) as well as strengthening company relationship with its stakeholders and other external environment in maintaining corporate sustainability (Handajani, Subroto, \& Saraswati, 2014).

The resource dependence theory is involved in the contribution of the board, namely, enhancing the authority, guidance, consultations, connect the companies with others stakeholders, form an external relationship and enhance the companies' problem solving (Shaukat, Qiu, \& Trojanowski, 2016). The emphasis on external resources and careful articulation of both strategic and tactical management in an organization is a hallmark of resource dependence theory (Davis \& Cobb, 2010).

\section{Agency Theory}

Jensen and Meckling (1976) had introduced the agency theory which describes that the selfinterested individuals are opportunistic therefore it only protects a few interests of principals and less possible to act for their own interests through means such as empire building, the 
consumption of corporate resources as perquisites, the avoidance of optimal risk investments, and manipulating financial figures to optimize compensation (Dey, 2008). From the agency theory perspective, corporate social responsibility is recognized to be the primarily the responsibility of the government and a "corruption of corporate resources that would be better spent on value-added internal projects or returned to shareholders". A majority of the studies undertaken on boards used agency theory to explain the board's role in corporate governance and highlight the importance of responsibility in board directors to protect the interests of shareholders (Rao, 2016).

From the previous study, most of the researcher used an agency theory in defining the role of board's director in an organization and describe the importance of their role in managing the shareholder's interest. However, Rao (2016) stated that the board's responsibility when considering the broader perspective of corporate governance is not limited to consideration of shareholders and monitoring management. The terms agency in this theory is referred to as managers while the principals as the shareholders in an organization.

Though both agency theories had suggested that diversity has the potential to enhance board effectiveness (enhancing independence and providing more pooled resources among board members), neither of these theories explains the effect that board diversity could have on strategy, decision making processes or performance (Rao, 2016).

\section{Corporate Social Responsibility(CSR)}

Even though there is a limitation on the research of board diversity towards CSR but the research is still suggesting that the diversification of board members may impact in a certain aspect especially environmental and community aspect. Most researchers had focused on determining the effect of board diversity on CSR while some others only specific on a certain components of CSR such as social performance, environmental performance, and corporate governance performance. When the firms are involved in the CSR issues in order to achieve their firm's objective, they may select to appoint the directors who have good skills, knowledge, background and expertise that can enhance the quality of CSR in a decisionmaking strategies and policies at both individual and group levels.

Notwithstanding this, the literature does suggest that diverse boards are positively associated with higher CSR performance (Rao, 2016). Board diversity in CSR was recently viewed as a pressing issue to the performance of companies around the world. Within this stream of literature, some studies have documented that diversity on corporate boards is positively related to financial performance (Harjoto, Laksamana, \& Lee, 2014). There is evidence exists stated that board composition tends to gain a positive effect on CSR performance (Webb 2004) and CSR reporting (Haniffa and Cooke 2005). Besides, this claim also had been supported by a previous research from Post (2011) which stated that it shows a positive impact on the diversification of board towards CSR.

Accordingly, more diverse board members lead to better perceptive and decision making where enabling board representative to efficiently alert with the pressing issue and boost a better impact on CSR (Bear et al., 2010). CSR has indicated the importance of board diversity in improving the company's strategy and their performance which can avoid them from a further business bankruptcy by making a good decision and improve their problem solving in avoiding risk. Further, by having a variety of diverse boards towards CSR, it indicates the firms for having a commitment to social justice when the firms are compliance with norms, have a positive working environment, a specific strategy in corporate surveillance, and the point of 
view of the firm's attention to women and minorities. Then, it can be considered that the firms have a commitment to social justice.

The diversity board of directors toward CSR play an important role in an organization where they control the governance and monitor the companies. However, if there is a lack of diversity and homogeneous boards in management, it can contribute to an important element which leading to general failures and weaknesses of governance. In addition, the board diversity in CSR showed an increased representation of moral and ethical views in the decision-making process, reduce myopic decision making, enhance new ideas and have better problem solving, and also improve corporate strategic planning and accountability of company (Handajani, Subroto, \& Saraswati, 2014). Moreover, the representation of board diversity in CSR can enhance the ethical corporate culture where at the same time it leads to a better understanding of the company's market position, creativity and innovation as well as more effective problems.

\section{Board Diversity \\ Board Gender}

Gender diversity had been categorized as an important problem that needs to deal with companies. It was recently regarded as a problem not only in internal diversification of board but involved in the government and familiar issues. Even though there are a number of women directors had occupied in the top-level management especially on board representative, but it becomes the pressing issue when the numbers of women in board-level increase year by year. Rao (2016) claims that there is a connection the diversification of board mainly women representative in companies' CSR.

Furthermore, Galbreath (2011) finds that women on board are much better compared to men on board as they respond well to multiple stakeholders due to their relationship building ability that portrays CSR. The women on board are more tend to gain a positive impact towards CSR (Dawar \& Singh, 2016).

In terms of the legislative on the women representation in the board committee, certain countries have applied to the system (Rao, 2016). This representation of women includes in Norway which is approximately $40 \%$, Sweden for $25 \%$, Spain for $40 \%$ of women directors and France for $50 \%$. Furthermore, in the European country, India, China and Middle Eastern countries have already applied the representative of women in their company as a board member' (Sealy et al., 2008). The male directors were perceived CSR as a 'win-win' business decision, whereas the women directors see CSR as an obligation to 'do the right thing' (Rao, 2016). Based on the statistical result, it shows that the board gender diversity was not a behavior obligation, but it gives a positive impact not only on a company performance but at the same time affect the corporate responsibility.

\section{Board Age}

Board age diversity basically involves in a wide of experience, differences in a decision making and efficient skills. Usually, a group of senior-level who is an older board can contribute a lot of experiences and provide a better opinion relating to the job scope, the accountability and ways to handle the risk management. Concerning the relationship between board age and CSR, the research indicates the board diversity may contribute to a positive relationship on CSR performance. According to Rao (2016), it is quite possible there is a group consists of different aged of people with different types of attitudes, values and perspectives and 
opinions. However, there is still no valid proof about the diversification of board age towards CSR (Rao, 2016). Additionally, a board that reach the age of 56 years and upwards have influence to implement governance composition and the development relating to the organization. The involvement of older commissioners will be able to encourage the implementation of policies and strategies for CSR (Handajani, Subroto, \& Saraswati, 2014). For a board director who reaches the age of 56 years and upwards, they are able to influence to implement governance composition and the company organization development. Furthermore, a different age in a group board of director is expected to not only have orientation and perspectives of short term performance, but also to appoint wider long term perspectives of the various interest of corporate stakeholders (Handajani, Subroto, \& Saraswati, 2014).

\section{Board Size}

Board size is the number of board of commissioners working in a corporate board. Many boards (larger boards) are less effective than smaller boards (Hermalin \& Weisbach, 2003). When a board has a smaller number of board members, they will be able to manage the company very well and more often play a role in controlling compared to a company with larger boards which are not able to function efficiently (Chaganti et al., 1985). Therefore, when the numbers of board are too large, it will increase the agency problem where there will have some of the board directors be a free rider (Uwuigbe et al., 2011).

Unfortunately, it will also contribute to some problem if the board has a too small of numbers as they will receive a less advantage in having an expert advice and opinion in the boardroom discussion compared to the large board numbers. The benefit of having a larger board is that it can enhance the company's value, as they provide a firm with members from different fields of expertise (Bukair \& Rahman, 2015). In contrast, having a large board can have a negative impact on decision making, the costs could outweigh the advantages (Akhatruddin et al., 2009), lead to problems in coordination (Jensen, 1993), and less effective to monitor top managers (Bukair \& Rahman, 2015).

Additionally, a larger number of boards also indicates that the presence of larger boards brings more experience and knowledge (Handajani, Subroto, \& Saraswati, 2014). According to Bukair \& Rahman (2015) find that the board size has no effect on a CSR disclosure as the business organizations are responsible to perform their duty in the best way. Therefore, it claims that there should be no differences in disclosure level between companies that have small or large board's size. This finding is consistent with previous studies which surprisingly shows a negative relationship with CSR disclosure (Arcay and Vázquez, 2005; Said et al., 2009). Even though there are few arguments on whether large board size will disclose the CSR more than the small-sized board of directors. According to Said, R et al. (2009) they find there is a positive relationship between board size and CSR.

\section{Board Independence}

Board of dependent directors are those who "have past or present business or family relationships to the firm" (Bohren and Strom, 2010, p. 1284). Nonetheless, the independent director is the person who conducts independent judgement and does not join the firm either directly or indirectly. From previous studies have found that it is very difficult to compare an independent director of the company with the other companies (Lim et al., 2007; Haniffa \& Cooke, 2002; Post et al, 2011; Rao et al., 2013). 
According to Post et al (2011) stated that the dependent (inside) and independent (outside) directors have different values, interests, and time horizons. The existence of dependent directors and independent board of directors may affect the corporate voluntary disclosure (Rao et al., 2013; Lim et al., 2007; Haniffa \& Cooke, 2002). This is due to outside directors play a crucial role in establish and oversee the corporate policy on voluntary disclosure (Ajinkya et al., 2005). The composition of board of directors is positively related to voluntary disclosure (mainly related to environmental and social issues) in the corporate annual report, and independent boards provide more voluntary disclosure about progressive and strategic information (Lim et al., 2007). The higher the proportion for independence director the more they should disclose information (Lim et al., 2007). Chau \& Gray (2010) find that there was a positive association between independent non-executive director proportion and the level of information disclosure. Chen and Jaggi (2000) and Cheng and Courtenay (2006) find that boards with a larger proportion of independent directors were significantly and positively associated with higher levels of voluntary disclosure.

With the increasing proportion of outside directors, it will lead to better environmental performance (Uwuigbe et al., 2011) and better philanthropy consciousness than insiders (Dunn \& Sainty, 2009). Increasing the number of the independent board will be effective in monitoring and ensuring management actions in carrying out social activities that are consistent with corporate stakeholder interest (Handajani, Subroto, \& Saraswati, 2014)

\section{Board Tenure}

Tenure generally represents the length of time for a person who has been sitting on board and can be related to the business experience of a board director (Setiyono \& Tarazi, 2014). According to Handajani, Subroto, \& Saraswati (2014), indicates that the long term board of directors will contribute a better knowledge and skills about the company and change their business surroundings. Board tenure diversity is described as a board that have both longstanding and newer directors, and tenure is generally considered to be a proxy for experience (Rao, 2016).

According to Hafsi and Turgut (2013), the result shows that the diversity of board tenure has no effect on the CSR performance. Additionally, the directors will have a less tenured and experienced as a board of directors if they might be too shy to speak up (Hafsi \& Turgut, 2013). Conversely, compared to the board of directors who have long-tenured or more experience as directors, they might become more familiar and efficient with the company management strategy and become close to their managers which prevents them from engaging in a controversial discussion (Hafsi \& Turgut, 2013). In both situations, board members likely have more to follow rather than lead or question when there is the situation which needs to be deal with the community aware and obligation of CSR problems (Hafsi \& Turgut, 2013).

Furthermore, Rao (2016) finds that firms with boards that have a majority of longer-tenured directors (over ten years of tenure) tend to produce a lower level of CSR reporting compared to those with a majority of shorter tenured directors. Plus, the result is consistent with a recent study by Handajani, Subroto, \& Saraswati (2014) that find boards with long-tenured directors tend to produce lower corporate social disclosure. They suggest that, even though longer tenure enhances understanding of the corporate business environment, however, longer tenured directors may not be able to serve optimally in directing the strategy and policy for long term corporate sustainability (Handajani, Subroto, \& Saraswati, 2014). Accordingly, Berberich \& Niu (2011) find long tenure board has negative consequences for 
CSR, due to the lack of effective oversight of executives. A long-term relationship between the boards of directors and executives will increase agency problem and lower the board's oversight function on executives (Byrd et al., 2010). The longer board tenure will provide better experience and understanding to corporate business environment, so as to lead to a better long-term strategy and policy for corporate sustainability (Handajani, Subroto, \& Saraswati, 2014).

\section{Methodology \\ Research Model}

This research applies the regression analysis which shows the calculation to measure the relationship between CSR with independent variables and control variables. The model is attempts to capture the factors of board diversity that are likely to be important in influencing the CSR. This regression analysis is important to test the theory (economics) and evaluate the policy which effect when the study relies on non-experimental data because multiple regression models can accommodate many of the explanatory variables that can be attributed.

The functional form was express as:

$\mathrm{CSR}=\mathrm{f}$ (gender, age, size, independence, tenure)

Hence our function can be estimated under the following model:

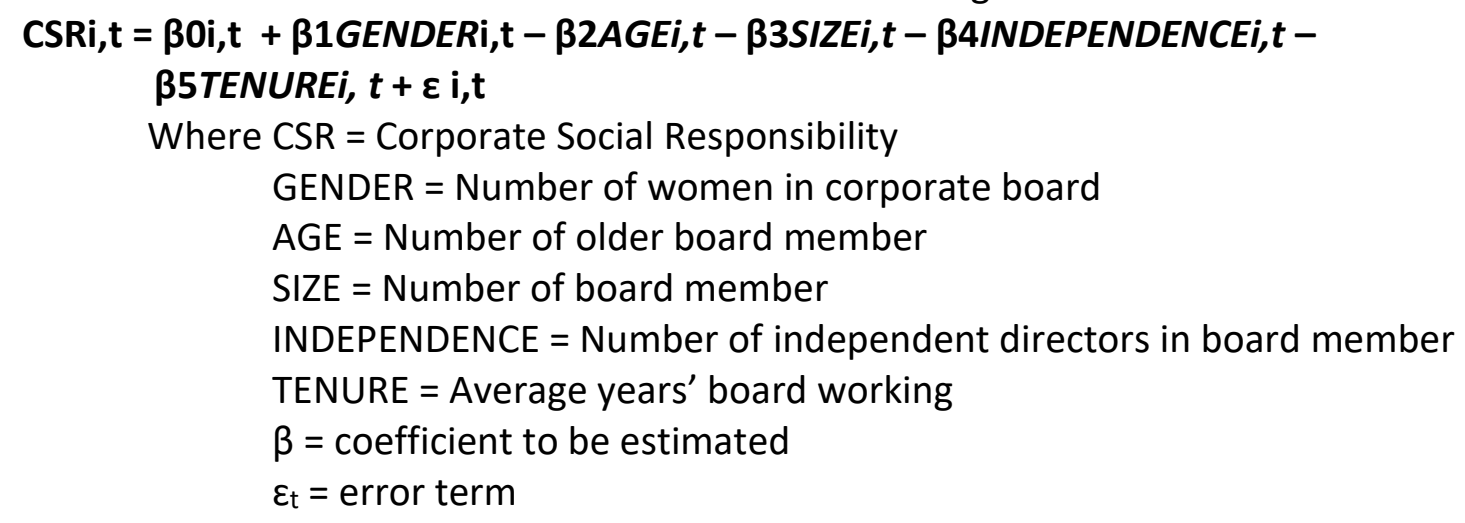

This study employs the (Ordinary Least Squares) OLS regression to test the relationship between CSR and several factors of board diversity, namely board gender, board age, board size, board independence and board tenure. According to Gujarati and Porter (2009), the OLS estimators are best linear unbiased estimator (BLUE) when the estimator is linear, unbiased, efficiency, consistency and lowest variance. 
Measurement of Variables

\begin{tabular}{|c|c|}
\hline Variables & Measurement \\
\hline CSR & $\begin{array}{l}\mathrm{CSRi}=\Sigma \mathrm{Xi} / \mathrm{ni} \\
\text { Where } \mathrm{ni}=\text { number of items expected for } \mathrm{i} \text { company, ni } \\
\leq 11 \\
\mathrm{Xi}=1 \text { if the item is disclosed, } 0 \text { if the item is not disclosed, } \\
\text { So that } 0 \leq \mathrm{CSRi} \leq 1 .\end{array}$ \\
\hline Board Gender & $x_{1}=\begin{array}{c}\text { Board Gender } \\
\text { Diversity Score }\end{array}=\frac{\text { Number of Female Board Members }}{\text { Board Size }} \times 2$ \\
\hline Board Age & $\begin{array}{l}\text { Board Age }=12 \text { i } P-\Sigma \\
P=\text { The proportion of directors } \\
\mathrm{I}=\text { Number of categories }\end{array}$ \\
\hline Board Size & Size $=\log 10$ (total assets) \\
\hline Board Independence & $\begin{array}{l}\text { outside directors } \\
\text { board size } \\
=\text { percentage }(\%)\end{array}$ \\
\hline Board Tenure & average of terms (years) board working in the company \\
\hline
\end{tabular}

Table 1: Measurement of Variables

\section{Hypothesis Development}

To assess the connection between the independent variables and dependent variables, hypothesis is required. The hypotheses are therefore evaluated in which may influence the company's efficiency:

Hypothesis 1: There is a positive relationship between diversification of board with CSR Hypothesis 2: There is a positive relationship between diversification of board gender with CSR

Hypothesis 3: There is a positive relationship between diversification of board age with CSR Hypothesis 4: There is a positive relationship between diversification of board size with CSR Hypothesis 5: There is a positive relationship between diversification of board independence with CSR

Hypothesis 6: There is a positive relationship between diversification of board tenure with CSR

\section{Contribution of the Study}

This study discovers various information particularly about the flow of company operations focusing on the administration group, shareholders, investors, government and public people. It requires major attention from the top level management in executing plans within the company organization. Other than that, this study will aid both academia and board directors to better comprehend the structure of the board diversity in delivering good governance towards the company objectives. It also will improve the financial professions about the factors that influence the CSR in the past and making better decision with the 
information that accessible around them. Nevertheless, this study provides board directors with information to assess the economic factors expectation and choices.

\section{Empirical Results and Findings \\ Diagnostic Analysis Result \\ Pearson Correlation Coefficient Analysis}

\begin{tabular}{|c|c|c|c|c|c|c|c|}
\hline Probability & CSR & BDGEN & BDIND & BDSIZE & BDAGE & BDTEN & FSIZE \\
\hline CSR & $\begin{array}{r}1.0000 \\
-\end{array}$ & & & & & & \\
\hline BDGEN & $\begin{array}{r}0.2388^{* * *} \\
0.0000\end{array}$ & $\begin{array}{r}1.0000 \\
-\end{array}$ & & & & & \\
\hline BDIND & $\begin{array}{r}0.2099 * * * \\
0.0001\end{array}$ & $\begin{array}{l}0.0490 \\
0.3607\end{array}$ & $\begin{array}{r}1.0000 \\
-\end{array}$ & & & & \\
\hline BDSIZE & $\begin{array}{l}0.1424 \\
0.0076\end{array}$ & $\begin{array}{l}0.0386 \\
0.4715\end{array}$ & $\begin{array}{r}-0.1516 \\
0.0045\end{array}$ & $\begin{array}{r}1.0000 \\
---\end{array}$ & & & \\
\hline BDAGE & $\begin{array}{r}0.1819 * * \\
0.0006\end{array}$ & $\begin{array}{l}0.0511 \\
0.3401\end{array}$ & $\begin{array}{l}0.1197 \\
0.0252\end{array}$ & $\begin{array}{l}0.1686 \\
0.0015\end{array}$ & $\begin{array}{r}1.0000 \\
-\end{array}$ & & \\
\hline BDTEN & $\begin{array}{r}-0.1385 \\
0.0095\end{array}$ & $\begin{array}{r}-0.1702 \\
0.0014\end{array}$ & $\begin{array}{r}-0.1347 \\
0.0116\end{array}$ & $\begin{array}{r}- \\
0.2726 * * * \\
0.0000 \\
\end{array}$ & $\begin{array}{l}0.1276 \\
0.0169\end{array}$ & $\begin{array}{r}1.0000 \\
----\end{array}$ & \\
\hline FSIZE & $\begin{array}{l}0.1935 \\
0.0003\end{array}$ & $\begin{array}{l}0.2280 \\
0.0000\end{array}$ & $\begin{array}{l}0.1675 \\
0.0017\end{array}$ & $\begin{array}{l}0.2395 \\
0.0000\end{array}$ & $\begin{array}{l}0.3055 \\
0.0000\end{array}$ & $\begin{array}{r}-0.2269 \\
0.0000\end{array}$ & $\begin{array}{r}1.0000 \\
----\end{array}$ \\
\hline
\end{tabular}

*** Correlation is significant at the 0.01 level (1-tailed)

** Correlation is significant at the 0.05 level (1-tailed)

* Correlation is significant at the 0.10 level (1-tailed)

$\mathrm{CSR}=$ Corporate social responsibility; $\mathrm{BDGEN}=$ Board Gender (Female); $\mathrm{BDIND}=$ Board Independence $;$ BDSIZE = Board Size $;$ BDAGE = Board Age $;$ BDTEN = Board Tenure $;$ FSIZE = Firm Size

\section{Table 2: Pearson Correlation Coefficient Test}

According to the table 2, the board gender (BDGENDER) is statistically significant effect with the CSR at $10 \%$ level of significance. This positive significant result from BDGENDER means that the board gender is positively correlated with CSR among the company on Bursa Malaysia.

From the table, it also indicates that the involvement of CSR with the independent variables of board independence, board size and board age have contributed to a positive significant correlation effects at $10 \%$ level of significance. It also indicates a sign of negative and positive significant correlation between the control variables and independent variables with the CSR. The board tenure (BDTEN) shows a negative relationship but it is significant correlation with CSR while the firm size specified that there was a positive relationship but not a significant relationship between firm size (FSIZE) and the CSR at $1 \%, 5 \%$ and $10 \%$ level of significance. 


\section{Descriptive Statistics Analysis}

\begin{tabular}{|c|c|c|c|c|c|}
\hline & Mean & Maximum & Minimum & Std. Dev. & Observation \\
\hline CSR & 0.5771 & 1.0000 & 0.0000 & 0.4947 & 350 \\
\hline BDGENDER & 0.2049 & 0.8889 & 0.0000 & 0.2058 & 350 \\
\hline BDIND & 0.4471 & 1.0000 & 0.1667 & 0.1314 & 350 \\
\hline BDSIZE & 8.7229 & 15.0000 & 4.0000 & 2.3173 & 350 \\
\hline BDAGE & 3.2912 & 4.8750 & 2.1667 & 0.4764 & 350 \\
\hline BDTEN & 1.9951 & 3.8333 & 0.9286 & 0.5857 & 350 \\
\hline FSIZE & 9.1104 & 11.8669 & 4.1220 & 1.2854 & 350 \\
\hline
\end{tabular}

Table 3: Descriptive Statistics Analysis

Table 3 above shows the result of descriptive statistics for the independent variables(IV) and the dependent variable(DV). The average of CSR performance which measures with the disclosure index is about $57.71 \%$ is higher for a sample of 50 companies from 2010 to 2016. Compared with the mean of CSR, the standard deviation was 0.4947 which is lower than the score of mean in CSR. In the IV of board gender (FGENDER), it shows that the increasing number of women on board impact the CSR performance with an average of 0.2049 . The range of BDGENDER with the maximum and the minimum score was respectively 0.8889 and 0.0000 while the standard deviation was 0.2058 .

Besides, the board independence (BDIND) has an average score of 0.4471 which shows that there is $45 \%$ of independence directors form a board size and the result of standard deviation is 0.1314 . The range for the highest and lowest number of BDIND were 1.0000 and 0.1667 respectively. While the total average score of the board size is 8.7229 which generates a positive relationship with CSR. The score of maximum and minimum BDSIZE were respectively 15.0000 and 4.0000 while the standard deviation of BDSIZE was contributed to 2.3173.

Furthermore, the total average of board age (BDAGE) was 3.2912 which the older the board member helps in improving long term sustainability and build good relations with the community and environment. The range of BDAGE with the maximum and the minimum score was respectively 4.8750 and 2.1667 while the standard deviation was 0.4764 . With regards to a board tenure (BDTEN) performance has the mean of 1.9951 with the range of maximum and minimum from 3.8333 to 0.9286 . The standard deviation is 0.5857 respectively.

Other than that, it shows that the average of descriptive statistics for the firm size (FSIZE) is higher compared to the other variables. With regards to the firm size (FSIZE) where it has been measured by using a log of total assets for each of 50 companies, the FSIZE had an average of 9.1104. From this average result of FSIZE, it indicates that most of the companies in Malaysia were relatively small. The score of maximum and minimum FSIZE were respectively 11.8669 and 4.1220 while the standard deviation of FSIZE was 1.2854. 


\section{Model Determination}

\section{The Breusch \& Pagan Lagrange Multiplier (LM Test)}

BP Lagrange Multiplier test is evaluated to determine if Pooled OLS regression or random effect model is more suitable for use in the research. The findings of the BP Lagrange Multiplier test are presented in Table 4 as below.

\begin{tabular}{|l|c|c|c|}
\hline \multirow{2}{*}{ Breusch-Pagan } & \multicolumn{3}{|c|}{ Test Hypothesis } \\
\cline { 2 - 4 } & Cross-Section & Time & Both \\
\cline { 2 - 4 } & 560.8920 & 2.898267 & $(0.0000)$ \\
\hline
\end{tabular}

Notes: $* * *, * *, *$ denote statistically significant at $1 \%, 5 \%$, and $10 \%$ level respectively.

\section{Table 4: The Breusch \& Pagan LM Test}

As shown in Table 4, the test indicated that the value from the BOTH column is the most appropriate benchmark to make the selection. The $p$-value is less than 0.01 and is statistically important, so the null hypothesis can be dismissed at a rate of 1 percent and there is proof of important variations between CSRs in Malaysian PLC. Rejection of null hypothesis indicates that the model of random effects is the more appropriate model to be applied in this study compared to the OLS.

\section{Hausman Test}

Since the consequences of BP Lagrange Multiplier test suggests that the random effects model is the appropriate model to be used, the next step is running the Hausman test to choose between the fixed effects model and random effects model, which is more suitable to use. The end result of Hausman check are illustrated in table below.

\begin{tabular}{|c|c|c|c|c|}
\hline \multicolumn{5}{|c|}{$\begin{array}{l}\text { Correlated Random Effects - Hausman Test } \\
\text { Equation: Untitled } \\
\text { Test cross-section random effects }\end{array}$} \\
\hline Test Summary & & Chi-Sq Statistics & Chi-Sq. d.f & Prob. \\
\hline Cross-section $r$ & & 9.141242 & 6 & $0.1658 * * *$ \\
\hline \multicolumn{5}{|c|}{ Cross-section random effects test comparisons } \\
\hline Variable & Fixed & Random & Var (Diff.) & Prob. \\
\hline BDGENDER & -0.064847 & -0.007845 & 0.000738 & 0.0359 \\
\hline BDIND & 0.014279 & 0.113333 & 0.003584 & 0.0980 \\
\hline BDSIZE & -0.004317 & 0.000783 & 0.000033 & 0.3734 \\
\hline BDAGE & 0.052778 & 0.075591 & 0.000621 & 0.3601 \\
\hline BDTEN & -0.027523 & -0.040442 & 0.000266 & 0.4286 \\
\hline FSIZE & 0.116465 & 0.083124 & 0.000983 & 0.2875 \\
\hline
\end{tabular}

Notes: $* * *, * *, *$ denote statistically significant at $1 \%, 5 \%$, and $10 \%$ level respectively.

\section{Table 5: Hausman Test}

The test above shows that the $p$-value is 0.1658 , which is larger than 0.01 and is statistically significant. Therefore, the null hypothesis can be rejected at $1 \%$ importance level. The 
rejection of null hypothesis concluded that fixed effect model is more applicable for this study.

Multiple Regression Analysis

4.3.1 Coefficient of Multiple Regression Analysis

\begin{tabular}{|c|c|c|c|c|c|}
\hline Variable & Coefficient & \multicolumn{2}{|c|}{ Standard Deviation } & t-Statistic & Probability \\
\hline BDGENDER & 0.4831 & \multicolumn{2}{|c|}{0.1247} & 3.8758 & 0.0001 \\
\hline BDIND & 0.7142 & \multicolumn{2}{|c|}{0.1992} & 3.5851 & 0.0004 \\
\hline BDSIZE & 0.0254 & \multicolumn{2}{|c|}{0.0118} & 2.1433 & 0.0328 \\
\hline BDAGE & 0.1291 & \multicolumn{2}{|c|}{0.0571} & 2.2603 & 0.0244 \\
\hline BDTEN & -0.0454 & \multicolumn{2}{|c|}{0.0471} & -0.9614 & 0.3371 \\
\hline FSIZE & 0.0143 & \multicolumn{2}{|c|}{0.0218} & 0.6573 & 0.5114 \\
\hline C & -0.5277 & \multicolumn{2}{|c|}{0.2616} & -2.0169 & 0.0445 \\
\hline \multicolumn{2}{|l|}{ R-squared } & 0.142020 & \multicolumn{2}{|c|}{ Mean dependent var } & 0.5771 \\
\hline \multicolumn{2}{|c|}{ Adjusted R-squared } & 0.127011 & \multicolumn{2}{|c|}{ S.D dependent var } & 0.4947 \\
\hline \multicolumn{2}{|c|}{ SE of regression } & 0.4622336 & \multicolumn{2}{|c|}{ Akaike info criterion } & 1.3143 \\
\hline \multicolumn{2}{|c|}{ Sum of squared resid } & 73.28624 & \multicolumn{2}{|c|}{ Schwarz criterion } & 1.3915 \\
\hline \multicolumn{2}{|l|}{ Log likelihood } & -223.0054 & \multicolumn{2}{|c|}{ Hannan-Quinn criter } & 1.3450 \\
\hline \multicolumn{2}{|l|}{ F-statistic } & 9.462670 & \multicolumn{2}{|c|}{ Durbin Watson stat } & 0.3770 \\
\hline \multicolumn{2}{|c|}{ Prob (F-statistic) } & 0.001000 & & & \\
\hline
\end{tabular}

* Correlation is significant at the 0.10 level (1-tailed)

Table 6: The coefficient of Multiple Regression Analysis

The R-Squared value of 0.1420 or $14.20 \%$ indicates that the variance of CSR is influenced by the variable of board diversity (board gender, board independence, board size, board age and board tenure) of $14.20 \%$. In another way, the board gender, board independence, board size, and board age have a significantly positive effect on CSR disclosure. Nonetheless, board tenure and the firm size have no significant effect on CSR disclosure.

Furthermore, there is a positive significant between board gender and firm probability which means that the increasing number of women on board director positively affects the performance of CSR disclosure. The result shows that board gender has a statistically significant effect on firm probability. Therefore, the null hypothesis between board gender and probability has rejected the hypothesis at $10 \%$ significant level. It is shown that when the variable of board gender is increasing by $1 \%$ will lead to an increasing $0.48 \%$ of probability. 
Hence, this result supports the finding from a prior study of Kruger (2010) that states the increasing number of women on boards will influence a better social behavior in a workplace and be able to focus more on the stakeholder welfare. It also has been supported by Darmadi (2010) that states the increasing number of women on board was able to develop a better corporate ethical behavior in CSR and give a positive effect to the performance of corporate social.

Another aspect to look on, it shows that there is also a positive relationship between the variable of board independence and probability. Therefore, it shows that board independence has a statistically significant effect on the firm probability which will lead the result should reject the null hypothesis at a $10 \%$ significant level. Hence, the decreasing of $1 \%$ of board independence will influence the increase of $0.71 \%$ of probability. Nevertheless, this finding does not support the prior study from Handajani, Subroto, \& Saraswati (2014) which states that the existence and the increasing number of independence director on board do not impact the CSR performance and ethical behaviour. Additionally, the argument from Handajani, Subroto, \& Saraswati (2014) states that the higher commitment on CSR does not affect by

having a higher number of independence director on board of companies.

In terms of board size, it indicates that there is a positive relationship between board size and firm profitability. As the variable is significant, therefore reject the null hypothesis at a $10 \%$ significant level. Thus, when the board size is decreased by $1 \%$, the profitability will increase by $2.54 \%$. This finding is support by Halme \& Huse (1997) and Dalton \& Dalton (2005) that proves the increasing number of board give more experience with various value, but the lower number of board director will influence other board members with a lack of experience in giving an opinion and recommendation during the annual board meeting. According to Handajani, Subroto, \& Saraswati (2014) claim that the higher number of a board member in a company will lead to a wide range of experience, knowledge, and skill which at the same time help the company to improve their performance and company policy.

Moreover, the finding results above show that there is a significant positive relationship between board age and firm profitability. The study is to reject the null hypothesis at $10 \%$ significant level. Thus, when the variable is decreased by $1 \%$, the profitability will increase by $12.91 \%$. This proves by Nyirenda (2011) stated that the influences of different age of generations help in improving a better decision making strategy and policy of the companies. The result of study supports the finding by Post et al (2011) that the existences of older board member with a wide experiences and knowledge is important in a long term sustainability and build good relations with community and environment while a younger board member helps in giving new ideas and recommendation on social policy and company strategies.

Moreover, from the result between board tenure and firm profitability shows that there is a negative relationship which is statistically not significant. The null hypothesis shows the result should be done not reject the null hypothesis at a $10 \%$ significant level. This is support by a previous study from Handajani et al. (2014), which stated that the companies with longer tenure board members will tend to bring a lower CSR performance. This is because the company with a longer tenure of board members will not be able to perform well in their role of oversight and executive's controls which gives the impact on the ethical policies of a company. Besides, Byrd et al (2010) stated that board members with a long-term tenure can influence and increase the agency problem which at the same time reduce the capability of the board member's in oversight their role in a company's organization. Besides, the control 
variables of the firm size and firm profitability show a positive relationship but not significant. Therefore, the null hypothesis in this variable should not be rejected. This is because from the result in the table above the $p$-value is exceed the value of $10 \%$ significance level, therefore the null hypothesis will be rejected.

Summary of Hypotheses

\begin{tabular}{|c|c|c|}
\hline Hypotheses & Results & $\begin{array}{l}\text { Supported/Not } \\
\text { supported }\end{array}$ \\
\hline $\begin{array}{l}\mathrm{H} 1 \text { :There is a relationship } \\
\text { between diversification of board with CSR }\end{array}$ & Positive relationship & Supported \\
\hline $\begin{array}{l}\mathrm{H} 2 \text { : There } \\
\text { is a relationship between diversification } \\
\text { of board gender with CSR }\end{array}$ & Positive relationship & Supported \\
\hline $\begin{array}{l}\text { H3: There is a relationship } \\
\text { between diversification of board age } \\
\text { with CSR }\end{array}$ & Positive relationship & Supported \\
\hline $\begin{array}{l}\text { H4: There is a relationship } \\
\text { between diversification of board size } \\
\text { with CSR }\end{array}$ & Positive relationship & Supported \\
\hline $\begin{array}{l}\text { H5: There is a relationship } \\
\text { between diversification of board } \\
\text { independence with CSR }\end{array}$ & Positive relationship & Supported \\
\hline $\begin{array}{l}\text { H6: There is a relationship } \\
\text { between diversification of board } \\
\text { tenure with CSR }\end{array}$ & Negative relationship & Not Supported \\
\hline
\end{tabular}

\section{Conclusion}

As a conclusion, it indicates that overall board diversity is approximately having a positive relationship with CSR. The results proof with strong evidence when all the variables of board diversity which are the board gender, board independence, board size, board age were found to have a positive and significant relationship with the CSR except for board tenure. This signifies that the firm with a higher level of board diversity will more fairly to have a higher level of CSR performance.

According to the Pearson Correlation Coefficient Analysis, all independent variables have significant correlation effects with CSR at $10 \%$ significance. Overall variables have positive relationship except for board tenure (BDTEN) that shows negative relationship. However, board tenure gives significant relationships except for firm size that do not show significant relationship with the CSR.

Additionally, based on the descriptive analysis, the average of CSR performance for a sample of 50 companies within 2010 until 2016 is high at $57.71 \%$. The standard deviation of the data mostly below 1 that indicates the data closely to the mean. It shows that the variables are reliable. Only board size and firm size more than 1 that indicates less reliable.

Referring to the results of Hausman Test, there is positive and significant association between board diversity and CSR whereby suitable to use Fixed Effects Model. This confirms that variety of board in the organization give important factors in CSR performance. 
Furthermore, there are a few important implications which need to be emphasized by a firm for a further determination. First, this study helps to enhance the firm's decision making strategy and corporate ethical behavior with a different perspective of board member in a company. The implementation of CSR towards board diversity will lead a company to expose with new and strategic ideas and; simultaneously remove narrow perspectives of certain ideas and decisions.

Besides, board diversity enables to develop the universal relationship to become more efficient. It also promotes the ability of the board to provide a better perspective in CSR based on the differences in board gender, age, size, board independence and tenure. Furthermore, board members with a wide range of experiences and knowledge are crucial in the long term company's sustainability and build valuable relations with a community and environment. Accordingly, this situation will benefit the companies with an improved public image through the commitment and other opportunities that can help them to grow and move to the next level.

There are a few limitations during the process of analyzing and interpreting the data in this study. First, the availability of the major data in this study is limited whereas some of the firm data collected were not available in their annual report. There are some of the companies which newly enter the industry has an incapability to perform CSR due to the limited cost of capital. Hence, changing the terms of the samples to other suitable companies as it had affected the precision of data and another potential data issue.

Looking at the future study of this research, it is encouraged to maintain an active older board member incorporate with long-term tenure and experience as they provide the firm with substantial skills, expertise and other values of useful experienced. Additionally, regarding the board gender where the number of women directors had occupied in the top-level management especially on board representative. Therefore, by encouraging more number of women on board can help to give a better concern in a shareholder's welfare and significantly influences the firms' supervision, and thus enhance corporate performance. This recommendation has been supported by Darmadi (2011) stated that the increasing number of women on board was able to develop a better corporate ethical behaviour in CSR and give a positive effect to the performance of corporate social.

\section{Acknowledgment}

This research would like to express the gratitude towards Universiti Malaysia Sarawak by giving Myra Special Short Term Grant Scheme under [F01 /SpSTG/1576/2017].

\section{References}

Ajinkya, B., Bhojraj, S., \& Sengupta, P. (2005). The association between outside directors, institutional investors and the properties of management earnings forecasts. Journal of accounting research, 43(3), 343-376.

Akhtaruddin, M., Hossain, M. A., Hossain, M., \& Yao, L. (2009). Corporate governance and voluntary disclosure in corporate annual reports of Malaysian listed firms. Journal of Applied Management Accounting Research, 7(1), 1.

Arcay, M. R. B., \& Vázquez, M. F. M. (2005). Corporate characteristics, governance rules and the extent of voluntary disclosure in Spain. Advances in Accounting, 21, 299-331. 
Bear, S., Rahman, N., \& Post, C. (2010). The impact of board diversity and gender composition on corporate social responsibility and firm reputation. Journal of Business Ethics, 97(2), 207-221.

Berberich, G., \& Niu, F. (2011). Director Busyness, Director Tenure and the Likelihood of Encountering Corporate Governance Problems. In CAAA Annual Conference.

Bilimoria, D. (2000). Building the business case for women corporate directors. In Women on corporate boards of directors (pp. 25-40). Springer, Dordrecht

Bøhren, O., \& Strom, R. O. (2010). Governance and politics: Regulating independence and diversity in the board room. Journal of Business Finance \& Accounting, 37(9-10), 12811308.

Bukair, A. A., \& Rahman, A. A. (2015). The effect of the board of directors' characteristics on corporate social responsibility disclosure by Islamic banks. Journal of Management Research, 7(2), 506.

Chaganti, R. S., Mahajan, V., \& Sharma, S. (1985). Corporate board size, composition and corporate failures in retailing industry [1]. Journal of management studies, 22(4), 400417.

Chau, G., \& Gray, S. J. (2010). Family ownership, board independence and voluntary disclosure: Evidence from Hong Kong. Journal of International Accounting, Auditing and Taxation, 19(2), 93-109.

Chen, C. J., \& Jaggi, B. (2000). Association between independent non-executive directors, family control and financial disclosures in Hong Kong. Journal of Accounting and Public policy, 19(4-5), 285-310.

Cheng, E. C., \& Courtenay, S. M. (2006). Board composition, regulatory regime and voluntary disclosure. The international journal of accounting, 41(3), 262-289.

Darmadi, S. (2011). Board diversity and firm performance: the Indonesian evidence. Corporate ownership and control Journal, 8.

Davis, G. F., \& Cobb, J. A. (2010). Corporations and economic inequality around the world: The paradox of hierarchy. Research in Organizational Behavior, 30, 35-53.

Dawar, G., \& Singh, S. (2016). Corporate social responsibility and gender diversity: A literature review. Journal of IMS Group, 13(1), 61-71.

Dey, A. (2008). Corporate governance and agency conflicts. Journal of Accounting Research, 46(5), 1143-1181.

Dunn, P., \& Sainty, B. (2009). The relationship among board of director characteristics, corporate social performance and corporate financial performance. International Journal of Managerial Finance, 5(4), 407-423.

Freeman, R. E., Wicks, A. C., \& Parmar, B. (2004). Stakeholder theory and "the corporate objective revisited". Organization science, 15(3), 364-369.

Galbreath, J. (2011). Are there gender-related influences on corporate sustainability? A study of women on boards of directors. Journal of management \& organization, 17(1), 17-38.

Hafsi, T., \& Turgut, G. (2013). Boardroom diversity and its effect on social performance: Conceptualization and empirical evidence. Journal of business ethics, 112(3), 463-479.

Handajani, L., Subroto, B., Sutrisno, T., \& Saraswati, E. (2014). Does board diversity matter on corporate social disclosure? An Indonesian evidence. Journal of Economics and Sustainable Development, 5(9), 8-16. 
Haniffa, R. M., \& Cooke, T. E. (2002). Culture, corporate governance and disclosure in Malaysian corporations. Abacus, 38(3), 317-349.

Harjoto, M., Laksmana, I., \& Lee, R. (2015). Board diversity and corporate social responsibility. Journal of Business Ethics, 132(4), 641-660.

Hermalin, B., \& Weisbach, M. (2003). Boards of Directors as an endogenously determined institution: a survey of the economic literature. Econ Policy Rev 9, 7-26.

Hillman, A. J., \& Dalziel, T. (2003). Boards of directors and firm performance: Integrating agency and resource dependence perspectives. Academy of Management review, 28(3), 383-396.

ljas, J. (2012). The impact of board gender diversity on corporate responsibility performance in the FTSE 100.

Jensen, M. C., \& Meckling, W. H. (1976). Theory of the firm: Managerial behavior, agency costs and ownership structure. Journal of financial economics, 3(4), 305-360.

Jensen, M. C. (2001). Value maximization, stakeholder theory, and the corporate objective function. Journal of applied corporate finance, 14(3), 8-21.

Jensen, M. C. (2002). Value maximization, stakeholder theory, and the corporate objective function. Business ethics quarterly, 235-256.

Kakabadse, N. (2007). The three orthos of CSR. Corporate Governance: The international journal of business in society, $7(1)$.

Kang, H., Cheng, M., \& Gray, S. J. (2007). Corporate governance and board composition: Diversity and independence of Australian Boards. Corporate Governance: An International Review, 15(2),194-207.

Krüger, P. (2009). Corporate social responsibility and the board of directors. Job Market Paper. Toulouse School of Economics, France.

Lim, S., Matolcsy, Z., \& Chow, D. (2007). The association between board composition and different types of voluntary disclosure. European Accounting Review, 16(3), 555-583.

Miller, T., \& Triana, D. C. M. (2009). Demographic diversity in the boardroom: Mediators of the board diversity-firm performance relationship. Journal of Management studies, 46(5), 755-786.

Pfeffer, J. (1972). Size and composition of corporate boards of directors: The organization and its environment. Administrative science quarterly, 218-228.

Post, C., Rahman, N., \& Rubow, E. (2011). Green governance: Boards of directors' composition and environmental corporate social responsibility. Business \& Society, 50(1), 189-223.

Rao, K. K., \& Tilt, C. A. (2013). Corporate governance and corporate social responsibility: A critical review. In Proceedings of the 7th Asia Pacific Interdisciplinary Research in Accounting Conference.

Rao, K., \& Tilt, C. (2016). Board composition and corporate social responsibility: The role of diversity, gender, strategy and decision making. Journal of Business Ethics, 138(2), 327-347.

Rao, K. (2016). Boards, Gender and Corporate Social Responsibility (CSR) (Doctoral dissertation, Flinders University, Flinders Business School.).

Rodrigues, P., \& Borges, A. P. (2015). Corporate social responsibility and its impact in consumer decision-making. Social Responsibility Journal, 11(4), 690-701.

Said, R., Hj Zainuddin, Y., \& Haron, H. (2009). The relationship between corporate social responsibility disclosure and corporate governance characteristics in Malaysian public listed companies. Social Responsibility Journal, 5(2), 212-226. 
Sealy, R., Vinnicombe, S., \& Singh, V. (2008). The female FTSE report 2008.

Selsky, J. W., \& Parker, B. (2005). Cross-sector partnerships to address social issues: Challenges to theory and practice. Journal of management, 31(6), 849-873.

Setiyono, B., \& Tarazi, A. (2014, October). Disclosure, ownership structure and bank risk: Evidence from Asia. In 27th Australasian Finance and Banking Conference.

Setiyono, B., \& Tarazi, A. (2018). Does diversity of bank board members affect performance and risk? Evidence from an emerging market. In Corporate Governance in Banking and Investor Protection (pp. 185-218). Springer, Cham.

Shaukat, A., Qiu, Y., \& Trojanowski, G. (2016). Board attributes, corporate social responsibility strategy, and corporate environmental and social performance. Journal of Business Ethics, 135(3), 569-585.

Ping, S. L. (2012). Corporate Governance and Strategic CSR Practices Influence on Credibility of Sustainability Report (Doctoral dissertation, USM).

Shirley, C., Suan, A. G., Leng, C. P., Okoth, M. O., Fei, N. B., \& PJU, K. D. (2009). Corporate social responsibility reporting in Malaysia: An analysis of Website reporting of Second Board companies listed in Bursa Malaysia. SEG Review, 2(2), 85-98.

Uwuigbe, U. N., Egbide, B. C., \& Ayokunle, A. M. (2011). The effect of board size and board composition on firms corporate environmental disclosure: a study of selected firms in Nigeria. Acta Universitatis Danubius. CEconomica, 7(5).

Knippenberg, V. D., Dreu, D. C. K., \& Homan, A. C. (2004). Work group diversity and group performance: an integrative model and research agenda. Journal of applied psychology, 89(6), 1008.

Velte, P. (2017). Does board composition have an impact on CSR reporting?. Problems and Perspectives in Management, 15(2), 19-35.

Walt, V. D. N., \& Ingley, C. (2003). Board dynamics and the influence of professional background, gender and ethnic diversity of directors. Corporate Governance: An International Review, 11(3), 218-234.

Webb, E. (2004). An examination of socially responsible firms' board structure. Journal of Management and Governance, 8(3), 255-277 